\title{
Seasonal variation in sleeping metabolic rate, thyroid activity, and leptin
}

Citation for published version (APA):

Plasqui, G., Kester, A. D. M., \& Westerterp, K. R. (2003). Seasonal variation in sleeping metabolic rate, thyroid activity, and leptin. American Journal of Physiology : Endocrinology and Metabolism, 285(2), E338E343. https://doi.org/10.1152/ajpendo.00488.2002

Document status and date:

Published: 01/01/2003

DOI:

10.1152/ajpendo.00488.2002

Document Version:

Publisher's PDF, also known as Version of record

Document license:

Taverne

Please check the document version of this publication:

- A submitted manuscript is the version of the article upon submission and before peer-review. There can be important differences between the submitted version and the official published version of record.

People interested in the research are advised to contact the author for the final version of the publication, or visit the DOI to the publisher's website.

- The final author version and the galley proof are versions of the publication after peer review.

- The final published version features the final layout of the paper including the volume, issue and page numbers.

Link to publication

\footnotetext{
General rights rights.

- You may freely distribute the URL identifying the publication in the public portal. please follow below link for the End User Agreement:

www.umlib.nl/taverne-license

Take down policy

If you believe that this document breaches copyright please contact us at:

repository@maastrichtuniversity.nl

providing details and we will investigate your claim.
}

Copyright and moral rights for the publications made accessible in the public portal are retained by the authors and/or other copyright owners and it is a condition of accessing publications that users recognise and abide by the legal requirements associated with these

- Users may download and print one copy of any publication from the public portal for the purpose of private study or research.

- You may not further distribute the material or use it for any profit-making activity or commercial gain

If the publication is distributed under the terms of Article $25 \mathrm{fa}$ of the Dutch Copyright Act, indicated by the "Taverne" license above, 


\title{
Seasonal variation in sleeping metabolic rate, thyroid activity, and leptin
}

\author{
Guy Plasqui, ${ }^{1}$ Arnold D. M. Kester, ${ }^{2}$ and Klaas R. Westerterp ${ }^{1}$ \\ ${ }^{1}$ Departments of Human Biology and ${ }^{2}$ Methodology and Statistics, \\ Maastricht University, 6200 MD Maastricht, The Netherlands
}

Submitted 7 November 2002; accepted in final form 17 March 2003

\begin{abstract}
Plasqui, Guy, Arnold D. M. Kester, and Klaas R. Westerterp. Seasonal variation in sleeping metabolic rate, thyroid activity, and leptin. Am J Physiol Endocrinol Metab 285: E338-E343, 2003; 10.1152/ajpendo.00488.2002.-We investigated seasonal variation in sleeping metabolic rate (SMR) and the possible relation to body composition, thyroid activity, and leptin. Twenty-five healthy volunteers were examined four times during the year: in spring (April, May), summer (July, August), autumn (October, November), and winter (January, February). Body composition was determined using a three-compartment model based on underwater weighing and the deuterium dilution method. SMR was measured during an overnight stay in a respiration chamber. A blood sample was taken for the analysis of free and total thyroxine, TSH, and leptin. SMR showed a significant seasonal variation $(P<0.01)$ with a maximum in winter $(4.54$ $\mathrm{kJ} / \mathrm{min})$ and a minimum in summer $(4.34 \mathrm{~kJ} / \mathrm{min})$. The amplitude was $0.10 \pm 0.02 \mathrm{~kJ} / \mathrm{min}$, and the phase was November 5 th. Season explained $17 \%$ of the intraindividual variation in SMR. The circannual rhythm in SMR could not be explained by changes in body composition, thyroid activity, or leptin. Interindividual variation in SMR was explained by fat-free mass $(P<0.001)$ and leptin $(P<0.001)$.
\end{abstract}

body composition; thyroid-stimulating hormones; thyroxine; ambient temperature

RESTING METABOLIC RATE (RMR), determined mainly by fat-free mass (FFM), is the main component of total energy expenditure and therefore an important factor in the study of energy metabolism and obesity. One aspect influencing RMR is environmental temperature, wherein RMR is higher in a cold environment (32). Environmental temperature includes room temperature as well as ambient temperature. If ambient temperature regulates RMR, one expects a seasonal variation in RMR. Osiba (20) measured four Japanese male adults monthly under standard conditions and found a distinct seasonal variation in sleeping metabolic rate (SMR) with a summer low-winter high difference of $16.3 \%$ of the mean. Kashiwazaki (11) reanalyzed the literature on seasonal fluctuations in RMR in populations not exposed to limitations in food availability. It was stated that both indoor and outdoor temperatures at the time of measurement influenced

Address for reprint requests and other correspondence: G. Plasqui, Dept. of Human Biology, Maastricht University, PO Box 616, 6200 MD Maastricht, The Netherlands (E-mail: G.Plasqui@HB.Unimaas.NL).
RMR and that seasonal influences persisted after controlling for indoor temperatures. On the contrary, a more recent study by Haggarty et al. (6) revealed no summer-winter differences in the RMR of adult males in the United Kingdom. The latter was one of the few studies including data on body composition to eliminate the possibility that the seasonal changes in RMR are due to changes in FFM.

Thyroid activity is known to be related to RMR (1, $20,28)$ and is upregulated in a cold environment (4, 28 ), which makes it a potential regulating factor in seasonal RMR changes. Osiba (20) measured proteinbound iodine in serum as a measure of thyroxine $\left(\mathrm{T}_{4}\right)$ content and found a seasonal variation with the peak in January. Other studies measuring free, reverse, or total triiodothyronine $\left(\mathrm{T}_{3}\right)$, free or total $\mathrm{T}_{4}$, or thyroidstimulating hormone (TSH) showed contradictory results regarding seasonal influences or the moment of peak concentrations $(15,18,24,29)$.

The recently discovered hormone leptin, produced by adipocytes, could also influence RMR and has been suggested as a local autocrine/paracrine regulator of TSH release $(7,19)$. Very little is known about seasonal influences on leptin. Donahoo et al. (3) found no effect of season on leptin concentrations in normal-weight men and women. Perry et al. (22) found a circannual rhythm for leptin in older African American men, but the data were cross-sectional.

Despite a wide interest in seasonal variation in RMR, there are some quite contradictory results and questions to be resolved. To our knowledge, there is no study on seasonal variation in RMR, including repeated measures of SMR, body composition, and hormonal influences in both men and women, not subject to limitations in food availability. This study was designed to investigate 1) a possible seasonal variation in SMR; 2) whether or not this variation is due to a change in body composition; 3) seasonal variation in thyroid function, represented as $\mathrm{TSH}$, free $\mathrm{T}_{4}$, and total $\mathrm{T}_{4}$, and its relation to SMR; and 4) a possible seasonal variation in leptin and its relation with SMR.

The costs of publication of this article were defrayed in part by the payment of page charges. The article must therefore be hereby marked "advertisement" in accordance with 18 U.S.C. Section 1734 solely to indicate this fact. 


\section{SUBJECTS AND METHODS}

\section{Subjects}

Subjects were 25 healthy volunteers (10 males and 15 females) between the ages of 20 and $30 \mathrm{yr}$, most of them working at the university. Detailed information about the objective and the protocol of the study was provided. Written informed consent was obtained, and the study was approved by the Ethics Committee of Maastricht University. Most subjects were working at the university, performing comparable activities. SMR, body composition, and a blood sample were obtained at subsequent time points: in spring (April, May), summer (July, August), Autumn (October, November), and winter (January, February). The subjects were not measured within 14 days before or after their vacations. Subjects' physical characteristics at baseline are shown in Table 1.

\section{$S M R$}

SMR was measured during an overnight stay in a respiration chamber. The chamber measured $14 \mathrm{~m}^{3}$ and was equipped with a bed, table, chair, freeze toilet, washing bowl, radio, television, and computer (26). Subjects entered the room at 2100 in the evening and left the room at 0730 in the morning. Energy expenditure was calculated from $\mathrm{O}_{2}$ consumption and $\mathrm{CO}_{2}$ production according to Weir's formula (33). SMR was defined as the average SMR during $\geq 3 \mathrm{~h}$ of sleep with the lowest activity measured by Doppler radar, usually between 0300 and 0600. Subjects were asked to consume their normal evening meal at home between 1800 and 1900. In order not to interfere with the subjects' normal feeding behavior and thus with energy balance, the meals were not standardized. Because SMR was measured $\geq 6 \mathrm{~h}$, and in general 8-11 $\mathrm{h}$ after the meal, the effect of dietinduced thermogenesis is assumed to be minimal (27).

The respiratory quotient ( $R Q$ ) was determined as a measure of substrate oxidation. Room temperature was held constant at $20 \pm 1^{\circ} \mathrm{C}$ every season to investigate whether the seasonal effect is present when short-term effects of temperature changes are controlled for.

\section{Body Composition}

Anthropometric measurements were taken in the morning after subjects left the respiration chamber. Body mass was measured on an electronic scale (Mettler Toledo ID1 Plus, Giessen, Germany) to the nearest $0.01 \mathrm{~kg}$. Height was measured to the nearest $0.1 \mathrm{~cm}$ (SECA Mod.220, Hamburg, Germany). Body volume was measured by underwater weighing. Residual lung volume was simultaneously measured with the helium dilution technique. Total body water (TBW) was measured by deuterium dilution according to the Maastricht protocol (34).

Body composition was calculated from body density and TBW using Siri's three-compartment model (30).

\section{Table 1. Subjects' characteristics at baseline}

\begin{tabular}{lcc}
\hline \hline & Women & Men \\
\hline$n$ & 15 & 10 \\
Age, yr & $25 \pm 2$ & $26 \pm 2$ \\
Height, m & $1.72 \pm 0.07$ & $1.82 \pm 0.08$ \\
Body mass, kg & $64.4 \pm 5.9$ & $69.2 \pm 9.6$ \\
BMI, kg/m ${ }^{2}$ & $21.9 \pm 1.9$ & $20.9 \pm 2.0$ \\
Body fat, \% & $26.1 \pm 5.5$ & $15.7 \pm 3.4$ \\
\hline
\end{tabular}

Values are means \pm SD. BMI, body mass index.

\section{Blood Sample}

After the anthropometric measurements and before the consumption of any food or drinks, a blood sample was taken for the analysis of leptin, total $\mathrm{T}_{4}$, free $\mathrm{T}_{4}$, and $\mathrm{TSH}$.

\section{Ambient Temperature}

Data on 24-h average ambient temperature were supplied by the Royal Dutch Meteorological Institute and were collected at a location near the university (Maastricht, Beek; $51^{\circ}$ North, $6^{\circ}$ East).

\section{Statistics}

All variables were tested for normal distribution and were log transformed if necessary. A general sinusoidal model was used to investigate a within-subjects seasonal variation in SMR and hormone levels

$$
Y=\mathrm{c}+\mathrm{A} \cdot \sin \left[\left(\mathrm{d}-\mathrm{d}_{0}\right) / 365 \cdot 2 \pi\right]
$$

or

$$
\begin{aligned}
Y=\mathrm{c}+\underbrace{\mathrm{A} \cdot \cos \left(2 \pi \mathrm{d}_{0} / 365\right)}_{\mathrm{b}_{1}} \cdot \underbrace{\sin (2 \pi \mathrm{d} / 365)}_{X_{1}} \\
\begin{array}{l}
-\underbrace{\mathrm{A} \cdot \sin \left(2 \pi \mathrm{d}_{0} / 365\right)}_{\mathrm{b}_{2}} \cdot \underbrace{\cos (2 \pi \mathrm{d} / 365)}_{X_{2}}
\end{array}
\end{aligned}
$$

where $\mathrm{c}$ is a constant, $\mathrm{A}$ is the amplitude, $\mathrm{d}$ is day of the year the measurement was done, and $\mathrm{d}_{0}$ is the phase. ANOVA was used to determine $b_{1}$ and $b_{2}$, and an $F$-test was used to determine the significance of the sinusoidal model. The amplitude and the phase were then calculated as

$$
\mathrm{A}=\left(\mathrm{b}_{1}{ }^{2}+\mathrm{b}_{2}{ }^{2}\right)
$$

and

$$
\mathrm{d}_{0}=365 / 2 \pi \cdot \operatorname{arcos}\left(\mathrm{b}_{1} / \mathrm{A}\right)
$$

To correct for the menstrual cycle, the phase of the menstrual cycle was put into the model. Measurements for women in the postovulation phase were coded 1, whereas those for men and for women in the preovulation phase were coded 0 .

A multiple regression analysis with a backward-selection procedure was performed to identify the determinants of interindividual variation in SMR. All analyses were done with SPSS 10.0 for Macintosh (SPSS, Chicago, IL) and Statview 5.0 for Macintosh (SAS Institute, Cary, NC). The statistical significance level was set at $P<0.05$.

\section{RESULTS}

\section{Seasonal Variation}

SMR and FFM. Mean values for SMR and FFM for men and women in each season are presented in Table 2. There were no significant differences in FFM over the year either for women or for men.

SMR showed a significant seasonal variation, with a summer minimum (August) winter maximum (February) $(P<0.01)$. Figure 1 shows mean SMR in the four seasons and the calculated sinusoidal curve. The mean value over the year was $4.44 \pm 0.50 \mathrm{~kJ} / \mathrm{min}$, the amplitude was $0.10 \pm 0.02 \mathrm{~kJ} / \mathrm{min}(2.2 \pm 0.5 \%)$, and the phase was November 5th. Mean SMR over the year 
Table 2. Average ambient temperature, SMR, FFM, FM, TSH, total $T_{4}$, free $T_{4}$, and leptin in different seasons

\begin{tabular}{|c|c|c|c|c|}
\hline & Spring & Summer & Autumn & Winter \\
\hline $\mathrm{SMR}, \mathrm{kJ} / \mathrm{min}$ & $4.80 \pm 0.70$ & $4.56 \pm 0.53$ & $4.72 \pm 0.58$ & $4.85 \pm 0.55$ \\
\hline $\mathrm{FM}, \mathrm{kg}$ & $10.8 \pm 2.6$ & $10.5 \pm 4.3$ & $10.7 \pm 3.5$ & $11.4 \pm 3.1$ \\
\hline $\mathrm{TSH}, \mathrm{mU} / \mathrm{l}$ & $1.4 \pm 0.6$ & $1.7 \pm 1.3$ & $1.3 \pm 0.7$ & $1.2 \pm 0.5$ \\
\hline Total $\mathrm{T}_{4}, \mathrm{nmol} / \mathrm{l}$ & $104 \pm 11$ & $105 \pm 15$ & $108 \pm 12$ & $101 \pm 9$ \\
\hline \multicolumn{5}{|l|}{ Women } \\
\hline $\mathrm{SMR}, \mathrm{kJ} / \mathrm{min}$ & $4.27 \pm 0.28$ & $4.14 \pm 0.30$ & $4.31 \pm 0.38$ & $4.29 \pm 0.29$ \\
\hline FFM, kg & $47.5 \pm 4.3$ & $47.4 \pm 4.5$ & $47.3 \pm 4.4$ & $47.7 \pm 4.4$ \\
\hline $\mathrm{FM}, \mathrm{kg}$ & $17.0 \pm 4.4$ & $17.3 \pm 4.1$ & $17.4 \pm 4.2$ & $17.1 \pm 4.7$ \\
\hline $\mathrm{TSH}, \mathrm{mU} / \mathrm{l}$ & $1.9 \pm 0.8$ & $2.0 \pm 0.8$ & $1.9 \pm 1.0$ & $1.7 \pm 0.5$ \\
\hline Total $\mathrm{T}_{4}, \mathrm{nmol} / \mathrm{l}$ & $112 \pm 17$ & $116 \pm 22$ & $112 \pm 18$ & $111 \pm 23$ \\
\hline Free $\mathrm{T}_{4}, \mathrm{pmol} / \mathrm{l}$ & $12.6 \pm 2.1$ & $12.1 \pm 1.9$ & $12.2 \pm 1.4$ & $12.6 \pm 2.0$ \\
\hline
\end{tabular}

Results are presented as means \pm SD. SMR, sleeping metabolic rate; FFM, fat-free mass; FM, fat mass; TSH, thyroid-stimulating hormone; $\mathrm{T}_{4}$, thyroxine.

was lower for women $(4.25 \pm 0.29 \mathrm{~kJ} / \mathrm{min})$ than for men $(4.73 \pm 0.58 \mathrm{~kJ} / \mathrm{min} ; P=0.01)$, but the amplitude $(0.08 \pm 0.03 \mathrm{~kJ} / \mathrm{min}$ or $1.9 \pm 0.7 \%$ for women vs. $0.14 \pm$ $0.04 \mathrm{~kJ} / \mathrm{min}$ or $3.0 \pm 0.8 \%$ for men) and the phase (October 13th for women, November 25th for men) were not significantly different between the sexes. There was no significant effect of the menstrual cycle on SMR over the year.

Figure 1 also shows the mean ambient temperature for each season and the sinusoidal curve for ambient temperature over the year. The seasonal pattern in ambient temperature was almost the exact opposite of the pattern in SMR, and the descending part of the temperature curve crossed the mesor (average value over the year) 1 wk before the phase of the SMR curve, suggesting a causal relationship.

Overnight, the $R Q$, as a measure of substrate oxidation, was not significantly different between seasons, being $0.83 \pm 0.03$ in spring, $0.84 \pm 0.04$ in summer, $0.81 \pm 0.04$ in autumn, and $0.82 \pm 0.03$ in winter.

Thyroid activity. Mean values \pm SD for women and men separately for each season are summarized in

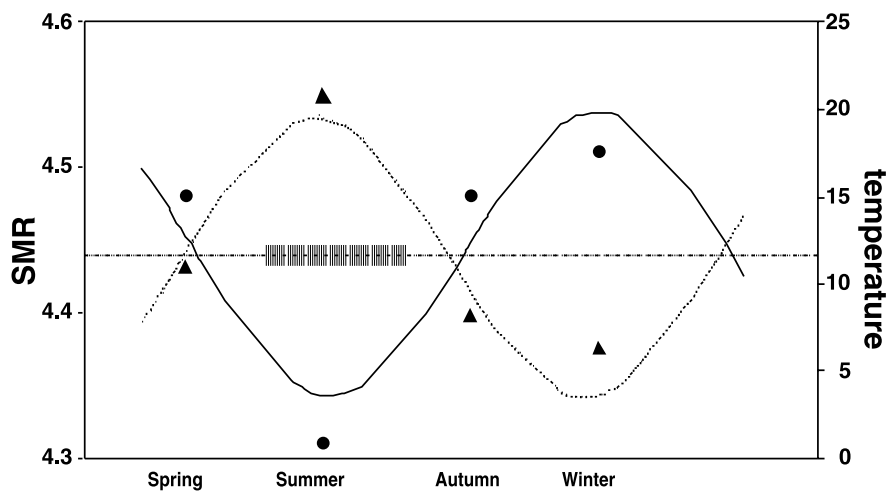

Fig. 1. Sinusoidal curve of sleeping metabolic rate $(\mathrm{SMR} ; \mathrm{kJ} / \mathrm{min}$; solid line) and ambient temperature $\left({ }^{\circ} \mathrm{C}\right.$; dashed line) and average values for each season for SMR $(\bullet)$ and ambient temperature (৯). For calculation of sinusoidal curves see METHODS, Statistics.
Table 2. With both men and women taken together, no seasonal variation in free $\mathrm{T}_{4}$, total $\mathrm{T}_{4}$, or natural logarithm of TSH $[\ln (\mathrm{TSH})]$ was observed. With men and women analyzed separately, a significant seasonal variation in free $\mathrm{T}_{4}$ was observed for men $(P<0.05)$. The amplitude was $0.49 \pm 0.18 \mathrm{pmol} / \mathrm{l}(3.6 \pm 1.3 \%)$, and the phase was November 6 th. The seasonal variation in free $\mathrm{T}_{4}$ was not related to SMR. In women, there were no seasonal effects.

Leptin. Mean values \pm SD for men and women for each season are presented in Table 2. There was no seasonal variation in $\ln ($ leptin) for women or for men.

\section{Determinants of SMR}

Intraindividual variation. For women and men together, season explained $17 \%$ of the intraindividual variation in SMR over the year $(12 \%$ for women and $25 \%$ for men). Ambient temperature also explained $17 \%$ and made the seasonal effect disappear. None of the measured hormones contributed significantly to the explanation of the seasonal variation in SMR. However, in men, there was an additional effect of total $\mathrm{T}_{4}$, which was negatively correlated with SMR and explained another $8 \%$ of the intraindividual variation in SMR.

Interindividual variation. To explain interindividual variation in SMR, average values of the four repeated measures were used in a multiple regression analysis with SMR as the dependent variable and sex, FFM, fat mass $(\mathrm{FM})$, total $\mathrm{T}_{4}$, free $\mathrm{T}_{4}, \ln (\mathrm{TSH})$, and $\ln ($ leptin) as the independent variables. Only FFM $(P<0.001)$ and $\ln$ (leptin) $(P<0.001)$ were significant predictors of SMR $\left(R^{2}=0.91\right)$. Coefficients, significance levels, partial and semipartial correlations, and $R^{2}$ values of the model are presented in Table 3.

\section{DISCUSSION}

The results show a seasonal variation in SMR with a minimum in summer and a maximum in winter. The 
Table 3. Significant predictors of SMR

\begin{tabular}{lccccc}
\hline \hline & Coefficients & $\mathrm{SE}$ & $P$ & Partial $R$ & Part $R$ \\
\hline Constant & 0.58 & 0.31 & & & \\
FFM & $6.75 \times 10^{-2}$ & $0.50 \times 10^{-2}$ & $<0.001$ & 0.95 & 0.91 \\
ln(Leptin) & 0.21 & 0.05 & $<0.001$ & 0.69 & 0.28 \\
\hline
\end{tabular}

Significant predictors of SMR, determined by stepwise regression analysis using backward selection, with SMR as the dependent variable and sex, FFM, FM, total $\mathrm{T}_{4}$, free $\mathrm{T}_{4}$, natural logarithm $(\ln ) \ln (\mathrm{TSH})$, and $\ln (\mathrm{leptin})$ as independent variables: coefficients, standard error (SE), significance $(P)$, partial (partial $R$ ) and semipartial correlation (part $R$ ), and $R^{2}$ of the model.

seasonal changes were not due to changes in FFM or any of the measured hormones. In men, there was a significant seasonal variation in free $\mathrm{T}_{4}$ that was not related to $\mathrm{SMR}$, whereas total $\mathrm{T}_{4}$ did not show a seasonal pattern but did explain an additional $8 \%$ of the intraindividual variation in SMR. FFM and leptin rather than FM explained between-subject variation in SMR.

The seasonal variation in SMR was highly significant $(P<0.01)$, with an amplitude of $0.10 \mathrm{~kJ} / \mathrm{min}$, or $2.3 \%$ of the mean, for women and men together. The summer low-winter high difference was two times the amplitude, or $4.5 \%$ of the mean. There was a difference in ambient temperature of $15^{\circ} \mathrm{C}$ between summer and winter (Table 2). Kashiwazaki (11) calculated that, at a constant room temperature of $20^{\circ} \mathrm{C}$, which was the case in this study, an increase in ambient temperature from 5 to $20^{\circ} \mathrm{C}$ would cause a drop in basal metabolic rate (BMR) of $4.2 \%$ for an average male subject (1.68 $\mathrm{m}, 65 \mathrm{~kg}, 40 \mathrm{yr}$ ). His calculation was based on data on 123 subjects from six different studies and is very close to the results found in this study. Osiba (20) calculated a change of $6.6 \%$ in $\mathrm{BMR}$ per $10^{\circ} \mathrm{C}$ on the basis of the data from nine Japanese males. He also found a higher BMR in spring than in autumn despite the same environmental temperature and suggested that it takes some time for the adaptive changes in BMR to take place. In this study, no significant differences in SMR between spring and autumn were found, but there were indications of a direct relationship between environmental temperature and SMR. Season and ambient temperature each explained the same amount of variation in SMR within subjects. Furthermore, the descending part of the temperature curve crossed the mesor $1 \mathrm{wk}$ before the phase of the SMR curve; in other words, the SMR curve lagged 1 wk behind the temperature curve. These results suggest that ambient temperature has a long-term metabolic effect.

Understanding of the mechanism behind these adaptive changes in SMR to season is still incomplete. Thyroid activity is known to be upregulated in a cold environment, but it is not clear whether this is caused by the drop in temperature itself or to increased food intake as a result of the cold exposure $(4,5,9,31)$. Furthermore, increased thyroid activity is able to increase basal metabolism (28), which makes the thyroid gland a possible regulator for seasonal changes in SMR. Studies on seasonal changes in thyroid hormones showed contradictory results. Seasonal variations in $\mathrm{T}_{3}$ and/or $\mathrm{T}_{4}(13,15,21)$ have been documented by some authors but contradicted by others (24). TSH was found to be higher in winter in middle-aged and older men and women (29) and in hyperthyroid patients treated with $\mathrm{T}_{4}$ (12) but not in young adults (29). Our data showed a seasonal variation in free $\mathrm{T}_{4}$ for men only. TSH and total $\mathrm{T}_{4}$ did not change significantly over the year either for women or for men. However, the seasonal variation in free $\mathrm{T}_{4}$ did not explain the observed seasonal trend in SMR. Total $\mathrm{T}_{4}$ did not show a seasonal pattern but was negatively correlated with SMR and explained an additional $8 \%$ of the intraindividual variation in SMR in men. The negative correlation might be due to a high turnover from $\mathrm{T}_{4}$ into $\mathrm{T}_{3}$, the metabolically active form of $\mathrm{T}_{4}$. Osiba (20) combined his measures of serum protein-bound iodine with measures of BMR and found peak values for both in winter, which might indicate a causal relationship. He stated that the correlation between protein-bound iodine and BMR was 0.77. However, he based his equation on the data of four persons each measured 12 times. Thus he included both intra- and intervariability in the regression analysis, which might lead to the wrong conclusion that the seasonal variation in BMR is due to changes in thyroid activity. Konno and Morikawa (12) found higher TSH concentrations in winter than in summer but that BMR remained unchanged. The fact that we did not find a significant relation between thyroid hormones and seasonal BMR changes does not necessarily mean that there is none. Blood levels of TSH display diurnal variation with a nocturnal rise. Despite the fact that the blood sample was taken at approximately the same time in the morning each season, a more continuous sampling might be recommended.

This is the first study to investigate leptin in relation to seasonal changes in RMR. There was no seasonal variation in leptin, and leptin was not related to the circannual rhythm in SMR. However, linear regression revealed FFM and leptin as the significant determinants of between-subject variation in SMR. Studies investigating the relationship between leptin and RMR showed contradictory results. Mackintosh and Hirsch (14) found no effect of leptin administration on RMR in normal-weight men. Hukshorn et al. (8) treated obese subjects with pegylated recombinant native human leptin (PEG-OB) or placebo, both in combination with a hypocaloric diet, and found no differences in $\triangle R M R$ (pre- and postintervention) between groups. Some studies found a positive relationship between RMR and leptin, but no corrections for FM were made $(10,17)$. 
When both FFM and FM were corrected for, no correlation $(16,25)$, or even a negative correlation, was found (2). A positive correlation was found in anorectic subjects, in whom leptin was suggested to play a role in the energy-sparing response to exposure to chronic energy deficiency (23). Despite the difficulty in comparing the different studies because of the wide variety in sex, age, and body mass index of the study populations and the different approaches to correct for FFM and/or FM, the general conclusion seems to be that leptin is not related to RMR when subjects are in energy balance. We used a stepwise regression approach and found that, after FFM $(P<0.001)$, leptin $(P<0.001)$ was a stronger predictor of RMR than FM $(P=$ not significant), resulting in a prediction of $91 \%$ of RMR. This indicates that, in this population of normalweight males and females, leptin is an important factor in the regulation of resting energy expenditure.

To our knowledge, this is the first study to investigate seasonal variation in RMR including both an accurate measurement of body composition and hormonal influences in both men and women. The study provides additional proof of an upregulation of RMR in winter. This supports the theory of an energy-producing mechanism as a protection against cold, even in the long term. We were unable to demonstrate a relationship of these seasonal SMR changes to activity of the thyroid gland. We took a single blood sample in the morning for the analysis of free and total $\mathrm{T}_{4}$ and TSH as a measure of thyroid function. Perhaps a more frequent and/or continuous sampling would provide a better picture of thyroid activity. Furthermore, other hormones, such as sex steroids or melatonin, might be important and interesting to investigate. Another possibility is to include measurements of body temperature. Current technologies allow accurate registration of rectal and/or intestinal temperature over $24 \mathrm{~h}$ or even longer.

We were unable to reveal the mechanism behind seasonal RMR changes, which makes it an interesting topic for future research. When doing so, it is, in our opinion, crucial to include an accurate measurement of body composition.

In conclusion, we found a distinct seasonal variation in SMR for both men and women, possibly triggered by environmental temperature. Furthermore, FFM and leptin were the only predictors of between-subject variability in SMR, indicating an important role for leptin in the regulation of RMR.

We thank Loek Wouters for the analysis of the deuterium samples, Joan Senden for the analysis of the serum leptin samples, and Paul Menheere for the analysis of the serum for thyroxine and TSH.

\section{REFERENCES}

1. Al-Adsani H, Hoffer LJ, and Silva JE. Resting energy expenditure is sensitive to small dose changes in patients on chronic thyroid hormone replacement. J Clin Endocrinol Metab 82: 1118-1125, 1997.

2. Bobbioni-Harsch E, Assimacopoulos-Jeannet F, Lehmann T, Munger R, Allaz AF, and Golay A. Leptin plasma levels as a marker of sparing-energy mechanisms in obese women. Int $J$ Obes Relat Metab Disord 23: 470-475, 1999.
3. Donahoo WT, Jensen DR, Shepard TY, and Eckel RH. Seasonal variation in lipoprotein lipase and plasma lipids in physically active, normal weight humans. J Clin Endocrinol Metab 85: 3065-3068, 2000.

4. Eastman CJ, Ekins RP, Leith IM, and Williams ES. Thyroid hormone response to prolonged cold exposure in man. $J$ Physiol 241: 175-181, 1974.

5. Evans SE and Ingram DL. The effect of ambient temperature upon the secretion of thyroxine in the young pig. $J$ Physiol 264: 511-521, 1977.

6. Haggarty P, McNeill G, Manneh MK, Davidson L, Milne E, Duncan G, and Ashton J. The influence of exercise on the energy requirements of adult males in the UK. $\mathrm{Br} J$ Nutr 72: 799-813, 1994.

7. Hsieh CJ, Wang PW, Wang ST, Liu RT, Tung SC, Chien WY, Lu YC, Chen JF, Chen CH, and Kuo MC. Serum leptin concentrations of patients with sequential thyroid function changes. Clin Endocrinol (Oxf) 57: 29-34, 2002.

8. Hukshorn CJ, Saris WH, Westerterp-Plantenga MS, Farid AR, Smith FJ, and Campfield LA. Weekly subcutaneous pegylated recombinant native human leptin (PEG-OB) administration in obese men. J Clin Endocrinol Metab 85: 4003-4009, 2000.

9. Ingram DL and Kaciuba-Uscilko $\mathbf{H}$. The influence of food intake and ambient temperature on the rate of thyroxine utilization. J Physiol 270: 431-438, 1977.

10. Jorgensen JO, Vahl N, Dall R, and Christiansen JS. Resting metabolic rate in healthy adults: relation to growth hormone status and leptin levels. Metabolism 47: 1134-1139, 1998.

11. Kashiwazaki H. Seasonal fluctuation of BMR in populations not exposed to limitations in food availability: reality or illusion? Eur J Clin Nutr 44: 85-93, 1990.

12. Konno $\mathbf{N}$ and Morikawa $\mathbf{K}$. Seasonal variation of serum thyrotropin concentration and thyrotropin response to thyrotropinreleasing hormone in patients with primary hypothyroidism on constant replacement dosage of thyroxine. J Clin Endocrinol Metab 54: 1118-1124, 1982.

13. Levine M, Duffy L, Moore DC, and Matej LA. Acclimation of a non-indigenous sub-Arctic population: seasonal variation in thyroid function in interior Alaska. Comp. Biochem. Physiol. 111A: 209-214, 1995.

14. Mackintosh RM and Hirsch J. The effects of leptin administration in non-obese human subjects. Obes Res 9: 462-469, 2001.

15. Maes M, Mommen K, Hendrickx D, Peeters D, D'Hondt P, Ranjan R, De Meyer F, and Scharpe S. Components of biological variation, including seasonality, in blood concentrations of TSH, TT3, FT4, PRL, cortisol and testosterone in healthy volunteers. Clin Endocrinol (Oxf) 46: 587-598, 1997.

16. Neuhauser-Berthold M, Herbert BM, Luhrmann PM, Sultemeier AA, Blum WF, Frey J, and Hebebrand J. Resting metabolic rate, body composition, and serum leptin concentrations in a free-living elderly population. Eur J Endocrinol 142: 486-492, 2000.

17. Nicklas BJ, Toth MJ, and Poehlman ET. Daily energy expenditure is related to plasma leptin concentrations in older African-American women but not men. Diabetes 46: 1389-1392, 1997.

18. Nicolau GY, Haus E, Plinga L, Dumitriu L, Lakatua D, Popescu M, Ungureanu E, Sackett-Lundeen L, and Petrescu E. Chronobiology of pituitary-thyroid functions. Rom $J$ Endocrinol 30: 125-148, 1992.

19. Ortiga-Carvalho TM, Oliveira KJ, Soares BA, and PazosMoura CC. The role of leptin in the regulation of TSH secretion in the fed state: in vivo and in vitro studies. J Endocrinol 174: 121-125, 2002.

20. Osiba S. The seasonal variation of basal metabolism and activity of thyroid gland in man. Jpn J Physiol 7: 355-365, 1957.

21. Pasquali R, Baraldi G, Casimirri F, Mattioli L, Capelli M, Melchionda N, Capani F, and Labo G. Seasonal variations of total and free thyroid hormones in healthy men: a chronobiological study. Acta Endocrinol 107: 42-48, 1984.

22. Perry HM III, Miller DK, Patrick P, and Morley JE. Testosterone and leptin in older African-American men: relationship to age, strength, function, and season. Metabolism 49: 1085-1091, 2000. 
23. Polito A, Fabbri A, Ferro-Luzzi A, Cuzzolaro M, Censi L, Ciarapica D, Fabbrini E, and Giannini D. Basal metabolic rate in anorexia nervosa: relation to body composition and leptin concentrations. Am J Clin Nutr 71: 1495-1502, 2000.

24. Postmes TJ, Van Hout JC, Saat G, Willems P, and Coenegracht J. A radioimmunoassay study and comparison of seasonal variation in plasma triiodothyronine and thyroxine concentrations in normal healthy persons. Clin Chim Acta 50: 189-195, 1974

25. Rosenbaum M, Nicolson M, Hirsch J, Murphy E, Chu F, and Leibel RL. Effects of weight change on plasma leptin concentrations and energy expenditure. J Clin Endocrinol Metab 82: 3647-3654, 1997.

26. Schoffelen PFM, Westerterp KR, and Saris WHM. A dualrespiration chamber system with automated calibration. $J$ Appl Physiol 83: 2064-2072, 1997.

27. Segal KR, Edano A, and Tomas MB. Thermic effect of a meal over 3 and 6 hours in lean and obese men. Metabolism 39: 985-992, 1990.

28. Silva JE. Thyroid hormone control of thermogenesis and energy balance. Thyroid 5: 481-492, 1995.
29. Simoni M, Velardo A, Montanini V, Faustini Fustini M, Seghedoni S, and Marrama P. Circannual rhythm of plasma thyrotropin in middle-aged and old euthyroid subjects. Horm Res 33: 184-189, 1990.

30. Siri WE. Body Composition from Fluid Spaces and Density: Analysis of Methods. Washington, DC: Natl. Acad. Sci. Natl. Res. Council, 1961.

31. Tomasi TE and Horwitz BA. Thyroid function and cold acclimation in the hamster, Mesocricetus auratus. Am $J$ Physiol Endocrinol Metab 252: E260-E267, 1987.

32. Warwick PM and Busby R. Influence of mild cold on $24 \mathrm{~h}$ energy expenditure in "normally" clothed adults. Br J Nutr 63: 481-488, 1990.

33. Weir JB. New methods for calculating metabolic rate with special reference to protein metabolism. J Physiol 109: 1-9, 1949.

34. Westerterp KR, Wouters $\mathbf{L}$, and van MarkenLichtenbelt WD. The Maastricht protocol for the measurement of body composition and energy expenditure with labeled water. Obes Res 3 : 49-57, 1995.

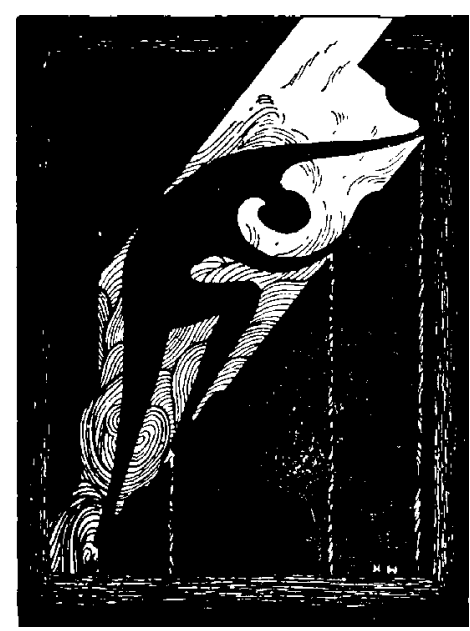

